\title{
ELECTROCHEMICAL STUDY OF FUMING SULPHURIC ACIDS-I. KINETIC PARAMETERS OF THE ANODIC AND CATHODIC REACTIONS ON PLATINUM ELECTRODES*
}

\author{
H. A. Garrera, J. S. W. Carrozza and A. J. Arvia \\ Instituto Superior de Investigaciones, Facultad de Química y Farmacia, \\ Universidad Nacional de La Plata, La Plata, Argentina
}

\begin{abstract}
Kinetic parameters related to the anodic and cathodic processes in the electrolysis of fuming sulphuric acids on bright platinum and platinized platinum electrodes have been established, the electrolyte being kept at rest. Experiments cover temperatures from 25 to $70^{\circ} \mathrm{C}$ and oleums with a sulphur trioxide concentration from about 5 to 28 per cent. The yields of the different anodic and cathodic products mentioned in a previous publication have been confirmed and results for others are given.

The anodic reaction is characterized by current/voltage curves which fit Tafel plots at high voltages, with a slope close to $2 \cdot 3(2 R T / F)$.

The cathodic current/voltage curves plotted according to the Tafel equation exhibit three different regions. (i) At voltages lower than $0.4 \mathrm{~V}$, a Tafel line with a slope of $2 \cdot 3(R T / F)$ is observed. (ii) At about $0.5 \mathrm{~V}$ a limiting current is shown. These regions are related to the reduction of sulphur trioxide. (iii) At voltages larger than $0.7 \mathrm{~V}$, a clear Tafel line region appears again, involving a $2 \cdot 3(2 R T / F)$ slope. The latter is related to the evolution of hydrogen and the simultaneous presence of a blue tinge in the oleums, which is attributed to the formation of disulphur trioxide.
\end{abstract}

Résumé-Les paramètres cinétiques des processus anodiques et cathodiques dans l'électrolyse des oléums sur des électrodes de platine poli et platine platinisé ont été établis, l'électrolyte étant au repos. Les expériences ont été réalisées a des températures de 25 à $70^{\circ} \mathrm{C}$ avec une concentration de trioxyde de soufre de 5 à 28 pour cent.

Les rapports des différents produits anodiques et cathodiques mentionnés dans une publication antérieure ont été confirmés; on présente aussi d'autres résultats.

Les courbes courant/voltage de la réaction anodique suivent la loi de Tafel à tensions élevées, avec une pente proche de $2,3(2 R T / F)$.

Les courbes cathodiques tracées de la même façon montrent trois régions différentes. (i) $\mathrm{A}$ des tensions de moins de $0,4 \mathrm{~V}$ on observe une droite avec un pente $2,3(R T / F)$. (ii) $\mathrm{A}$ des tensions d'environ $0,5 \mathrm{~V}$, on a trouvé un courant limite. Ces deux régions (i) et (ii) sont déterminées par la réduction du trioxide de soufre. (iii) A des tensions de plus de $0,7 \mathrm{~V}$ on a retrouvé une droite de Tafel avec une pente de $2,3(2 R T / F)$. Celle-ci est en relation avec l'évolution de l'hydrogène et l'apparition simultanée d'une teinte bleue dans l'électrolyte, qu'on a attribuée a la formation de trioxyde de disoufre.

Zusammenfassung-Man ermittelte die kinetischen Parameter der Anoden- und Kathodenvorgänge bei der Elektrolyse von rauchender Schwefelsäure an Platin- und platinierten Platinelektroden in ruhendem Elektrolyten. Die Versuchstemperatur wurde zwischen 25 und $70^{\circ} \mathrm{C}$, der Schwefeltrioxydegehalt des Oleums zwischen ungefähr 5 und $28 \%$ variiert. Die Zusammensetzung der kathodischen und anodischen Reaktionsprodukte, wie sie in einer früheren Arbeit beschrieben wurden, konnten bestätigt werden, daneben werden die Ergebnisse weiterer Versuche bekanntegegeben.

Die anodische Reaktion ist gekennzeichnet durch Strom-Spannungskurven, welche bei hohen Spannungen Tafel-Charakter mit einer Steigung von beinahe $2,3(2 R T / F)$ annehmen.

Die als Tafel-Beziehungen aufgezeichneten kathodischen Strom-Spannungskurven weisen drei verschiedene Gebiete auf. (A) Bei Spannungen unterhalb von $0,4 \mathrm{~V}$ erhält man eine Gerade mit der Steigung 2,3(2RT/F). (B) Bei ungefähr $0,5 \mathrm{~V}$ tritt ein Grenzstrom auf, welcher von der Reduktion des Schwefeltrioxyds/herrührt. (C) Bei Spannungen oberhalb $0,7 \mathrm{~V}$ ergibt sich wiederum eine Gerade mit deutlichem Tafel-Charakter und einer Steigung von 2,3(2RT/F). Diese dritte Zone steht in Beziehung zur Wasserstoffentwicklung und zu der gleichzeitigen Blaufärbung des Oleums, welche der Bildung von Schwefelsesquioxyd zugeschrieben wird.

* Manuscript received 31 July 1967. 


\section{INTRODUCTION}

THE ELECTROLYsis of fuming sulphuric acids was studied in early times ${ }^{1,2}$ and the main purpose was then to determine the reaction products and to establish whether the electrochemical oxidation of sulphur dioxide to sulphur trioxide could be achieved. Results obtained by electrolysing the oleums at temperatures up to $285^{\circ} \mathrm{C}$ showed that the principal cathodic product was sulphur dioxide, although under certain conditions the formation of sulphur on the cathode also occurred. At the anode oxygen was evolved. ${ }^{2}$ The electrochemical oxidation of sulphur dioxide is particularly interesting for the electrochemical formation of sulphuric acid, as reported recently in a paper on the electrolysis of sulphur dioxide-saturated sulphuric acid solutions on platinized platinum electrodes. ${ }^{3}$

A recent investigation ${ }^{4}$ shows that various processes simultaneously occur in the electrolysis of oleums. Thus, during the cathodic reaction the formation of sulphur dioxide, hydrogen gas, sulphur and disulphur trioxide was reported. The last dissolves in the oleum giving a deep blue tinged solution. The anodic reaction, on the other hand, shows an oxygen yield lower than that expected if it were the only reaction product, and a corresponding increase of the oxidizing power of the fuming acid in the anodic compartment. This preliminary work also raised the question about the mechanism of the electrochemical reduction of sulphur trioxide and the relationship of this process to other already known electrochemical reductions. ${ }^{5}$ The current/ voltage curves determined in the course of that work also indicate that both the cathodic and anodic processes only occur with an appreciable rate at relatively large voltages, so that those processes are activated electrochemical reactions.

From the fundamental standpoint it is particularly interesting to compare the electrochemical behaviour of oleums to that of aqueous sulphuric acid solutions, ${ }^{6}$ as well as to that of molten bisulphates, ${ }^{7-11}$ taking into account the structural differences of the corresponding systems and the influence on the kinetics of the electrode reactions.

The purpose of the present work is to extend the knowledge of the kinetics of those processes occurring in the electrolysis of fuming sulphuric acids. This paper, which is part of a series on the electrochemistry of oleums, is mainly concerned with the kinetics of the electrode reactions with the electrolyte at rest.

\section{EXPERIMENTAL TECHNIQUE}

\section{Description of the cell}

An air-tight Pyrex glass electrolysis cell was used. It consists of three main compartments. The one lodging the working electrode is of about $100 \mathrm{~cm}^{3}$ capacity and has conventional gas and liquid sample collectors. The second compartment is the counter-electrode section, which is connected to the working electrode section by means of a $\Omega$-shaped tubing having a fritted glass disk. The third section contains the reference electrode and is connected to the rest of the cell through a tube ending in a Luggin-Haber capillary tip placed close to the working electrode to prevent any large pseudo-ohmic drop. The working electrode was made from $99.9 \%$ pure platinum foil and consisted of a plate $1 \mathrm{~cm}^{2}$, welded to a glass-sheathed platinum wire for electrical contact.

Experiments were performed on bright platinum and platinized platinum electrodes. In the former case, the working electrodes were previously cleaned and polished with a suspension of alumina in alcohol and then used as cathodes in a $1 \mathrm{~N}$ sulphuric acid 
solution with a current of $0 \cdot 1 \mathrm{~A}$ for $1 \mathrm{~h}$, to produce a large hydrogen evolution on the electrode surface. After this treatment the electrodes were stored for a short time in the fuming sulphuric acids and finally dipped into the electrolysis cell.

Platinized platinum electrodes were made by electrolysis of a chloroplatinic acid solution $^{12}$ using a previously cleaned platinum base as cathode. Afterwards the electrodes were treated as already described.

The counter-electrode was similarly made. The reference electrode was also made of platinum, dipped into the fuming acid. Thus a symmetrical electrochemical system was employed.

\section{Electrolytes}

The electrolytes were made indifferently from the following chemicals: (i) Carlo Erba A.R. fuming sulphuric acid with a "free" sulphur trioxide content $C_{\mathrm{SO}_{3}}=$ 19 per cent. (ii) Baker's A.R. fuming sulphuric acid $C_{\mathrm{SO}_{3}}=28$ per cent. (iii) Mallinckrodt, A.R. concentrated sulphuric acid $C_{\mathrm{H}_{2} \mathrm{SO}_{4}}=97$ per cent. The purity and concentration of each chemical was checked by chemical analysis.

The electrolyte composition was established by volumetric determination of "free" sulphur trioxide and sulphur dioxide. The analysis was done with a LungeRey pipette and the known analytical procedures. ${ }^{13-15}$ Each determination was made at least twice and the concentrations of "free" sulphur trioxide and sulphur dioxide were known to within 1 per cent. The concentration of $\mathrm{SO}_{3}$ changed from 0 to about 30 per cent and that of $\mathrm{SO}_{2}$ from 0 to a maximum value of about $0.5 \mathrm{~N}$.

Sulphur dioxide solutions were made by bubbling the purified gas through fuming sulphuric acid at ordinary temperature and atmospheric pressure and also by electrochemical preparation in situ.

\section{Electrical circuitry}

A conventional electrolysis circuit was fed with regulated dc power packs of different ranges. Current regulation was obtained by means of a set of Hellipot potentiometers and wire resistors up to about $50 \mathrm{~K} \Omega$, and changed from a few $\mu \mathrm{A}$ to about $50 \mathrm{~mA}$, it being measured either with a Microva AL-4 or a Pye scalamp galvanometer or a Siemens-Halske ammeter. The working electrode potential $v s$ the reference electrode was measured with a high impedance Knick voltmeter.

A galvanostatic circuit was employed to measure the pseudo-ohmic drop between the electrodes. Traces of the build-up and decay curves were photographed in a Tektronix 545-A oscilloscope screen and the $I R$ drop was evaluated from the observed instantaneous jump of potential between the initial potential and the origin of the trace.

\section{Experimental procedure}

The electrolysis cell was placed in a circulating thermostatic bath and experiments were performed at 25,50 and $70 \pm 0.05^{\circ} \mathrm{C}$.

After a constant temperature and a steady potential were achieved the electrolysis was started by changing the working electrode potential continuously and taking increasing or decreasing current readings in nearly logarithmic progression.

The experimental set-up permitted a very rapid stabilization of the current and the elcctrode potential at high cds. 


\section{RESULTS}

\section{Yields of anodic products}

A previous study 4 has shown that the oxygen formation yield at the anode at room temperature is lower than expected, assuming that oxygen is the only reaction product. This is certainly due to the formation of persulphuric acids. As a matter of fact, during the electrolysis of sulphuric acid (density 1.35-1.50) persulphuric acids are formed at the anode (peroxidisulphuric and permonosulphuric acids). ${ }^{16}$ Thus, to evaluate the

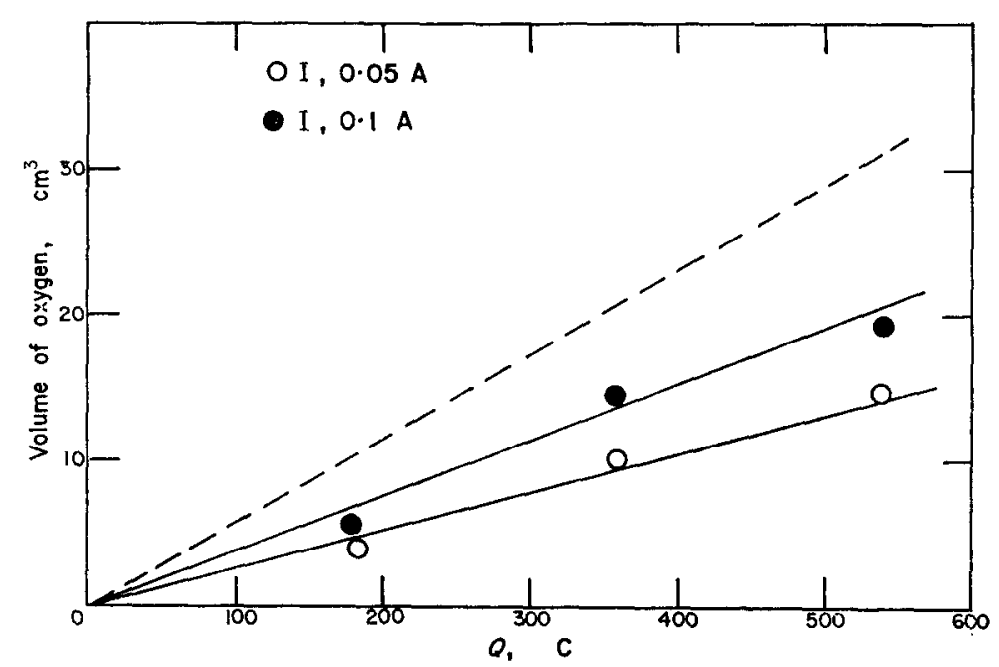

Frg. 1. Oxidizing power of anolyte, expressed as oxygen gas vs charge passed.

Dotted line corresponds to theoretical 100 per cent oxygen evolution; $25^{\circ} \mathrm{C}$; fuming sulphuric acid, $C_{\mathrm{Si}_{9}}, 27 \cdot 7$ per cent; platinized platinum.

yield of other anodic products besides oxygen, the oxidizing power of the anodic solution was determined by titration. Results obtained with platinized platinum electrodes are shown in Fig. 1. The anodic yield expressed as the equivalent volume of oxygen is on the average 0.45 at $I=0.05 \mathrm{~A}$ and 0.65 at $I=0.1 \mathrm{~A}$. These figures are complementary to the oxygen yield determined under the same experimental conditions.4 Oxygen gas and persulphuric acids are thus the main reaction products at the anode at lower temperatures. At $70^{\circ} \mathrm{C}$ the oxygen yield increases and the oxidizing power of the anolyte after the electrolysis is negligible. This fact agrees with the thermal stability of the persulphuric acids and with previous investigations performed at higher temperatures. ${ }^{2}$

If the anodic yield related to peroxidisulphuric acid and permonosulphuric acid in aqueous sulphuric acid is taken into account, a dependence on the current density and sulphuric acid concentration is observed. ${ }^{17-19}$ Thus, the formation of permonosulphuric acid is relatively more favoured than that of peroxidisulphuric acid at higher concentration of sulphuric acid. The anodic yield of the permonosulphuric acid is about 20 per cent in the electrolysis of sulphuric acid of about 100 per cent at a cd of $0.075 \mathrm{~A} / \mathrm{cm}^{2}$.

Sulphur dioxide probably oxidizes too, when dissolved in oleums, similary to what has been observed in aqueous media. ${ }^{3}$ 


\section{Yields of cathodic products}

Products formed at the cathode are mainly sulphur dioxide, hydrogen and disulphur trioxide. The sulphur dioxide yield was determined at different cds and temperatures and evaluated by titration of the reducing power of the catholyte with standard procedures. Results are shown in Fig. 2, where the reducing power is expressed as sulphur dioxide normality $v s$ charge passed. At $25^{\circ} \mathrm{C}$ and $I=0.025 \mathrm{~A}$, the sulphur dioxide yield was 0.75 and approached 1 as the temperature increased. These results are complementary to the yields of hydrogen and disulphur trioxide previously determined.4

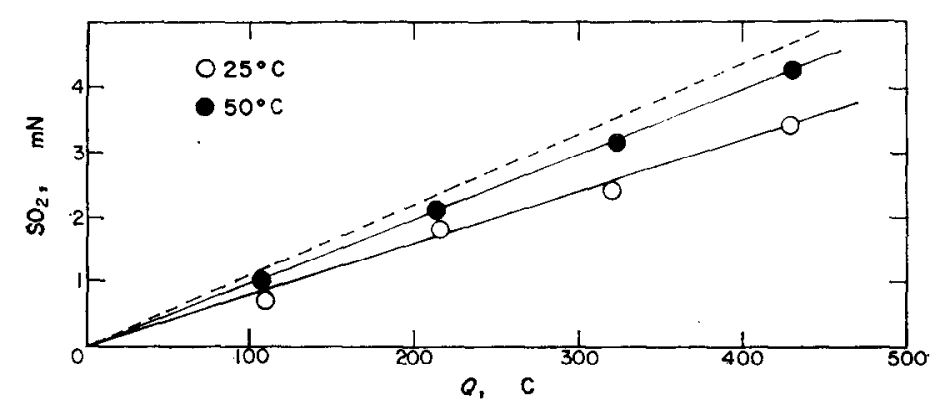

FIG. 2. Reducing power of catholyte, expressed as sulphur dioxide normality, vs charge passed. $I=0.025 \mathrm{~A}$; fuming sulphuric acid; $C_{80}, 27.7$ per cent.

Dotted line corresponds to theoretical 100 per cent sulphur dioxide formation.

It should be emphazised that at lower cds when no visible hydrogen gas formation occurs, the amount of sulphur dioxide is still slightly lower than that expected on the basis of a single reaction. This may be in part due to (i) a further electrochemical reduction of sulphur dioxide to sulphur, which is left undissolved, specially when low concentration oleums are used (ii) loss of sulphur dioxide into the gaseous phase, since its solubility in the acid is apparently low.

\section{Anodic current/voltage curves}

Anodic current/voltage curves corrected for the pseudo-ohmic drop, and plotted according to the Tafel equation, present two well-defined regions, as shown in Figs. 3 and 4. At a fixed cd platinized platinum electrodes exhibit a lower voltage than bright platinum electrodes in the whole range of current investigated. The initial potential as well as the initial portion of the current/voltage curve are rather sensitive to the electrode pre-history, ie whether it has been previously used as anode or cathode in the same electrolyte. Thus, when a first experiment was performed the starting potential was about a few $\mathrm{mV}$ either more positive or negative than the reference electrode, while after successive runs were made at high positive potentials, a rest potential of the order of $0.1 \mathrm{~V}$ was observed, quite unsatisfactory as far as its reproducibility was concerned. The same observation also applies to cathodic experiments done at high negative potentials.

The current stabilization in the low voltage region took over $1.5 \mathrm{~h}$. This also applied to cathodic experiments at low voltages. The low voltage region covers an appreciable large cd range when platinized platinum electrodes are employed at $70^{\circ} \mathrm{C}$ 


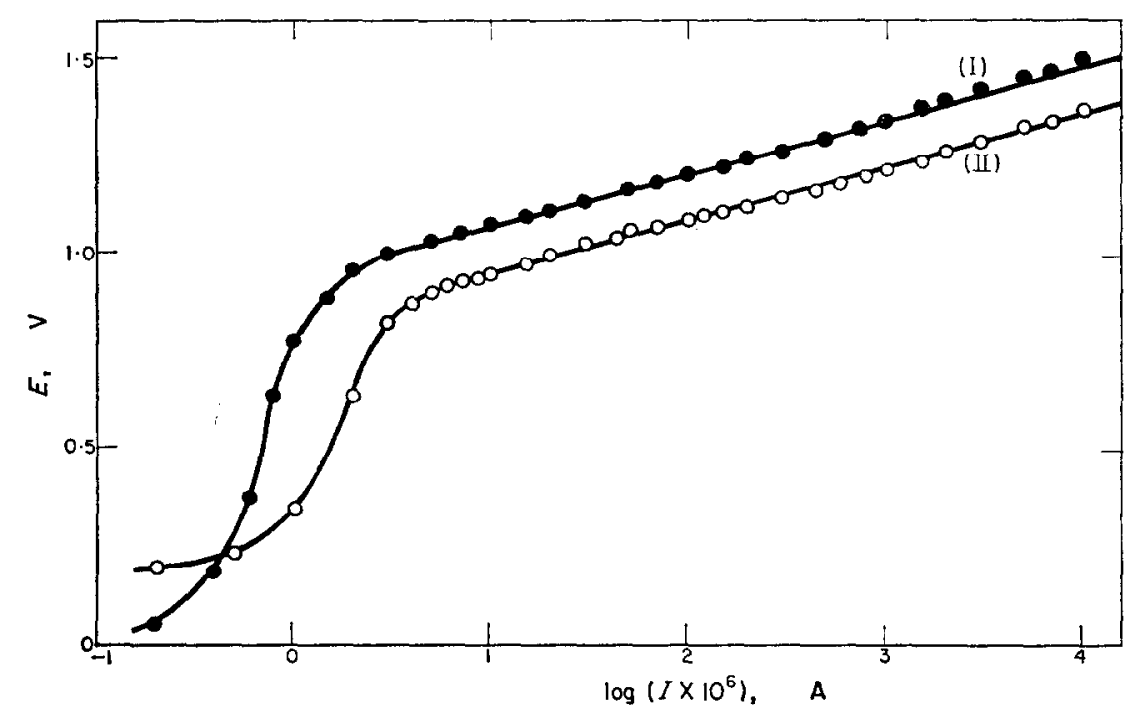

Fig. 3. Anodic Tafel plot. Experiments on bright platinum electrodes.

(I) Fuming sulphuric acid: $C_{\mathrm{sO}_{3}}, 7.7$ per cent; $C_{8_{2}}, 0.010 \mathrm{~N} ; 25^{\circ} \mathrm{C}$.

(II) Fuming sulphuric acid: $\mathrm{C}_{\mathrm{BO}_{3}}, 15 \cdot 1$ per cent; $\mathrm{C}_{\mathrm{SO}_{2}}, 0.033 \mathrm{~N} ; 50^{\circ} \mathrm{C}$.

At higher positive potentials the current/voltage curves bend up, approaching a limiting current region, which has no definite relationship either with the sulphur dioxide or with the sulphur trioxide concentrations in oleums.

Beyond $0.7 \mathrm{~V}$ a linear increase of voltage with $\log (\mathrm{cd})$ is again observed, involving a clear anodic Tafel slope, $\left(b_{\mathrm{T}}\right)_{\mathrm{a}}$, very close to $2 \cdot 3(2 R T / F)$ either for bright platinum or platinized platinum electrodes. The extrapolation of the straight lines to $E=0$ yields an apparent exchange cd, $\left(i_{0}\right)_{a}$, between $10^{-15}$ and $10^{-12} \mathrm{~A} / \mathrm{cm}^{2}$ for bright platinum electrodes and between $10^{-10}$ and $10^{-12} \mathrm{~A} / \mathrm{cm}^{2}$ for platinized platinum electrodes.

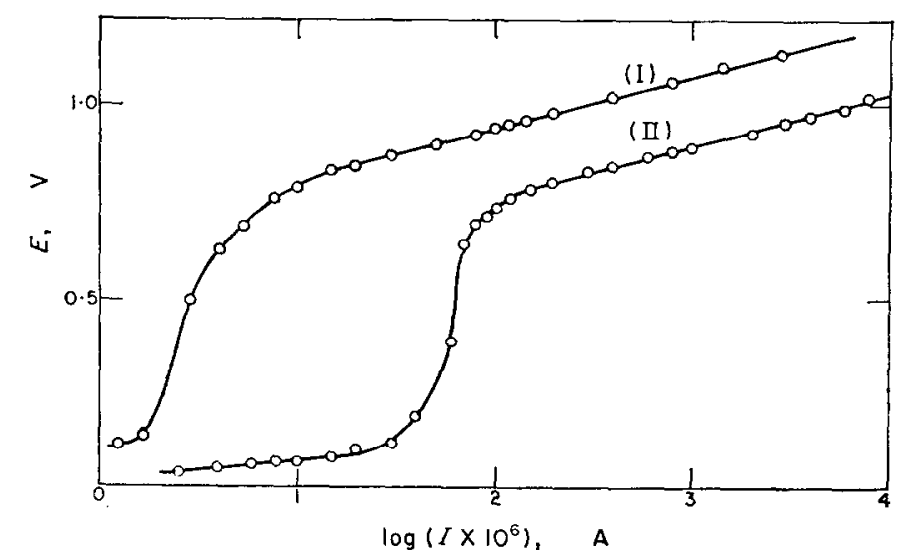

FIG. 4. Anodic Tafel plot. Experiments on platinized platinum electrodes.

(I) Fuming sulphuric acid: $\mathrm{C}_{\mathrm{so}_{3}}, 28$ per cent; $C_{\mathrm{8O}_{2}}, 0.02 \mathrm{~N} ; 25^{\circ} \mathrm{C}$.

(II) Fuming sulphuric acid: $C_{\mathrm{SO}_{3}}=6$ per cent; $C_{\mathrm{SO}_{2}}=0.05 \mathrm{~N} ; 70^{\circ} \mathrm{C}$. 
TABle 1. Kinetic Parameters From anodic CURRent/Voltage CURVES

\begin{tabular}{|c|c|c|c|c|c|}
\hline Run & $\begin{array}{c}\text { Temp } \\
{ }^{\circ} \mathrm{C}\end{array}$ & $\begin{array}{c}C_{\mathrm{SO}_{3}} \\
\left(\% \text { free } \mathrm{SO}_{3}\right)\end{array}$ & $\underset{\mathrm{N}}{C_{\mathrm{SO}_{2}}}$ & $\frac{\left(b_{\mathbf{T}}\right)_{\mathbf{8}}}{\mathbf{V}}$ & $\begin{array}{c}-\log \left(i_{0}\right)_{\mathbf{a}, \mathbf{r}}=0 \\
\left(i_{0} \text { in } \mathrm{A} / \mathrm{cm}^{2}\right)\end{array}$ \\
\hline \multicolumn{6}{|c|}{ Bright Pt electrodes } \\
\hline 38 & $25.0 \pm 0.05$ & $15 \cdot 0$ & 0.025 & $0.120 \pm 0.005$ & $15.1 \pm 0.4$ \\
\hline 43 & $25 \cdot 0$ & $7 \cdot 7$ & $0 \cdot 011$ & $0 \cdot 120$ & $14 \cdot 2$ \\
\hline 40 & $50 \cdot 0$ & $15 \cdot 1$ & 0.033 & 0.125 & $12 \cdot 8$ \\
\hline 46 & $50 \cdot 0$ & $8 \cdot 5$ & 0.021 & $0 \cdot 130$ & $12 \cdot 1$ \\
\hline 41 & $70 \cdot 0$ & $14 \cdot 8$ & 0.044 & $0 \cdot 140$ & $11 \cdot 9$ \\
\hline 48 & $70 \cdot 0$ & $8 \cdot 3$ & 0.025 & $0 \cdot 130$ & $11 \cdot 7$ \\
\hline \multicolumn{6}{|c|}{ Platinized Pt electrodes } \\
\hline 21 & $25.0 \pm 0.05$ & $28 \cdot 0$ & 0.005 & $0.120 \pm 0.005$ & $11.6 \pm 0.4$ \\
\hline 26 & $25 \cdot 0$ & $28 \cdot 0$ & 0.020 & 0.130 & $11 \cdot 2$ \\
\hline 50 & $25 \cdot 0$ & $8 \cdot 1$ & 0.026 & $0 \cdot 130$ & $11 \cdot 9$ \\
\hline 33 & $50 \cdot 0$ & $15 \cdot 2$ & 0.022 & $0 \cdot 130$ & $10 \cdot 7$ \\
\hline 52 & $50-0$ & $8 \cdot 1$ & 0.026 & $0 \cdot 135$ & $10 \cdot 3$ \\
\hline 23 & $70 \cdot 0$ & $28 \cdot 0$ & 0.009 & 0.150 & $8 \cdot 6$ \\
\hline 54 & $70 \cdot 0$ & 5.8 & 0.046 & $0 \cdot 140$ & 9.5 \\
\hline
\end{tabular}

As temperature increases the linear Tafel region maintains its slope close to $2 \cdot 3(2 R T / F)$ and an increase of the apparent exchange $c d$ is observed. In this region the stabilization of current and voltage was very fast. No definite effect on the oxygen evolution, which clearly occurs in this region of the current/voltage curve, is observed, either with sulphur dioxide concentration or with the amount of sulphur trioxide in the oleum.

\section{Cathodic current/voltage curves}

Plots of voltage $v s \log (\mathrm{cd})$ are shown in Figs. 5 and 6. At low electrode potentials a linear Tafel plot with a slope, $\left(b_{\mathrm{T}}\right)_{\mathrm{c}}$, very close to $2 \cdot 3(R T / F)$ is observed. The linear region covers about three logarithmic decades up to a voltage of about $0.3 \mathrm{~V}$. By extrapolation of the Tafel line to $E=0$, the exchange $c d,\left(i_{0}\right)_{c}$, referred to the apparent electrode area, is obtained. Exchange cds are between $10^{-7}$ and $10^{-8} \mathrm{~A} / \mathrm{cm}^{2}$ for bright

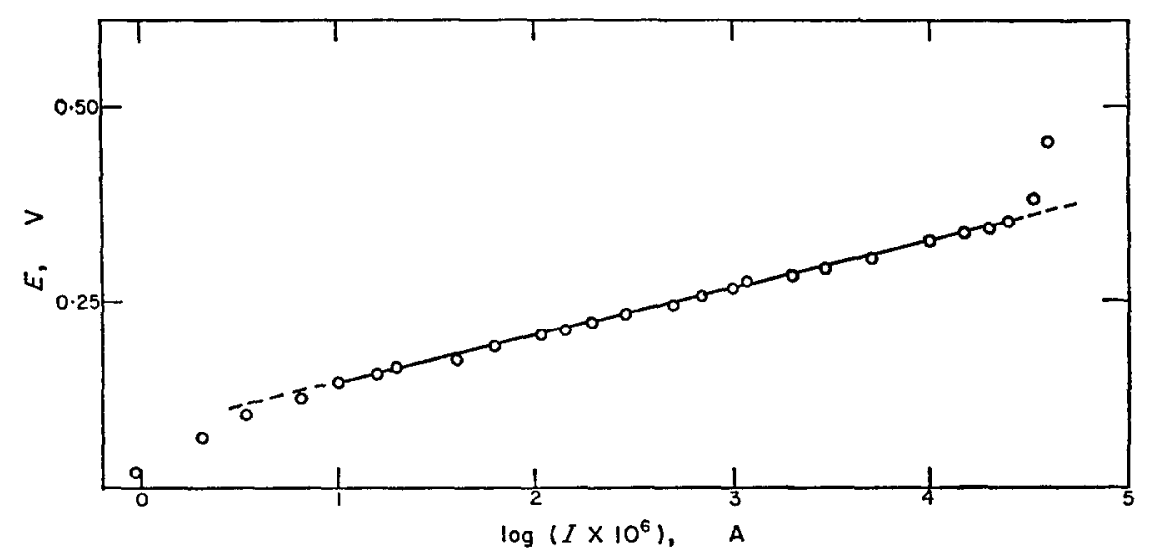

Fig. 5. Cathodic Tafel plot.

Fuming sulphuric acid: $C_{\mathrm{SO}_{3}}, 28$ per cent; $C_{\mathrm{SO}_{3}}, 0.005 \mathrm{~N}$; platinized platinum; 


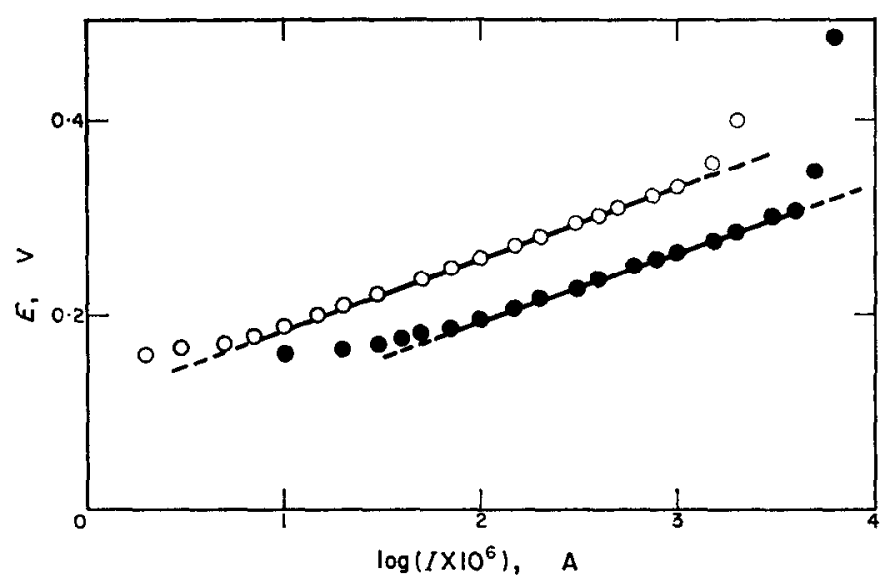

FIG. 6. Cathodic Tafel plot. Experiments on bright platinum electrodes.

(I) Fuming sulphuric acid: $C_{\mathrm{BO}_{\mathrm{g}}}: 8.5$ per cent; $C_{\mathrm{BO}}, 0.021 \mathrm{~N} ; 50^{\circ} \mathrm{C}$.

(II) Fuming sulphuric acid: $C_{\mathrm{SO}_{8}}, 8.25$ per cent; $C_{\mathrm{BO}_{2}}, 0.025 \mathrm{~N} ; 70^{\circ} \mathrm{C}$.

platinum electrodes and between $10^{-5}$ and $10^{-7} \mathrm{~A} / \mathrm{cm}^{2}$ for platinized platinum electrodes, under the present experimental conditions. The results obtained from the cathodic current/voltage curves are assembled in Table 2 . In the Tafel line region up to $E \approx 0.5 \mathrm{~V}$, no visible hydrogen gas evolution was observed, it occurring only at much higher voltage and in the region beyond the limiting current, as referred to below. At electrode potentials higher than $0.3 \mathrm{~V}$ the line bends up, approaching a limiting cd, which, at constant temperature, increases with the "free" sulphur trioxide content in the oleum.

The relationship between sulphur trioxide concentration and limiting current, without any further correction of the latter, is apparently linear, at least at the higher

TABLE 2. KINETIC PARAMETERS FROM CATHODIC CURRENT/VOLTAGE CURVES

\begin{tabular}{|c|c|c|c|c|c|c|}
\hline Run & $\underset{{ }^{\circ} \mathbf{C}}{\text { Temp }}$ & $\left(\%\right.$ free $\left.\mathrm{SO}_{\mathrm{s}}\right)$ & $\mathrm{C}_{\mathrm{SO}_{2}}$ & $\stackrel{\left(b_{\mathbf{r}}\right)_{\mathbf{c}}}{\mathbf{V}}$ & $\begin{array}{c}-\log \left(i_{0}\right)_{\mathrm{c}, \mathrm{n}=0} \\
\left(i_{0} \text { in } \mathrm{A} / \mathrm{cm}^{2}\right)\end{array}$ & $\begin{array}{c}-\log \left(i_{\mathrm{L}}\right)_{\mathrm{c}} \\
\left(i_{\mathrm{L}} \text { in } \mathrm{A} / \mathrm{cm}^{2}\right)\end{array}$ \\
\hline \multicolumn{7}{|c|}{ Bright Pt Electrodes } \\
\hline $\begin{array}{l}37 \\
44 \\
39 \\
45 \\
42 \\
47\end{array}$ & $\begin{array}{l}25 \cdot 0 \pm 0 \cdot 05 \\
25 \cdot 0 \\
50 \cdot 0 \\
50 \cdot 0 \\
70 \cdot 0 \\
70 \cdot 0\end{array}$ & $\begin{array}{r}15 \cdot 0 \\
7 \cdot 7 \\
15 \cdot 1 \\
8 \cdot 5 \\
14 \cdot 7 \\
8 \cdot 3\end{array}$ & $\begin{array}{l}0.025 \\
0.011 \\
0.033 \\
0.021 \\
0.044 \\
0.025\end{array}$ & $\begin{array}{l}0.058 \pm 0.002 \\
0.060 \\
0.062 \\
0.070 \\
0.068 \\
0.070\end{array}$ & $\begin{array}{l}7.92 \pm 0.15 \\
7.95 \\
7 \cdot 61 \\
7 \cdot 72 \\
6.24 \\
6.79\end{array}$ & $\begin{array}{l}1 \cdot 70 \pm 0.10 \\
2 \cdot 52 \\
1 \cdot 46 \\
2 \cdot 42 \\
1 \cdot 46 \\
2 \cdot 12\end{array}$ \\
\hline \multicolumn{7}{|c|}{ Platinized Pt electrodes } \\
\hline $\begin{array}{l}22 \\
32 \\
49 \\
27 \\
34 \\
51 \\
24 \\
30 \\
35 \\
53\end{array}$ & $\begin{array}{l}25 \cdot 0 \pm 0.05 \\
25 \cdot 0 \\
25 \cdot 0 \\
50 \cdot 0 \\
50 \cdot 0 \\
50 \cdot 0 \\
70 \cdot 0 \\
70 \cdot 0 \\
70 \cdot 0 \\
70 \cdot 0\end{array}$ & $\begin{array}{r}28 \cdot 0 \\
16 \cdot 3 \\
8 \cdot 1 \\
28 \cdot 2 \\
15 \cdot 2 \\
8 \cdot 1 \\
28 \cdot 0 \\
28 \cdot 0 \\
16 \cdot 0 \\
5 \cdot 8\end{array}$ & $\begin{array}{l}0.005 \\
0.017 \\
0.026 \\
0.031 \\
0.022 \\
0.026 \\
0.008 \\
0.035 \\
0.021 \\
0.047\end{array}$ & $\begin{array}{l}0.065 \pm 0.002 \\
0.060 \\
0.062 \\
0.066 \\
0.072 \\
0.065 \\
0.060 \\
0.056 \\
0.070 \\
0.070\end{array}$ & $\begin{array}{l}7 \cdot 23 \pm 0 \cdot 15 \\
5 \cdot 75 \\
6 \cdot 94 \\
5 \cdot 12 \\
5 \cdot 00 \\
3 \cdot 82 \\
5 \cdot 27 \\
4 \cdot 97 \\
4 \cdot 63 \\
4 \cdot 84\end{array}$ & $\begin{array}{l}1 \cdot 40 \pm 0.10 \\
1 \cdot 70 \\
2 \cdot 40 \\
1 \cdot 18 \\
1 \cdot 40 \\
2 \cdot 52 \\
1 \cdot 10 \\
1 \cdot 15 \\
1 \cdot 44 \\
2 \cdot 32\end{array}$ \\
\hline
\end{tabular}


concentrations of sulphur trioxide. But no definite conclusion can be drawn under the present conditions. The question has later been adequately studied by means of the platinum rotating disk electrode, and results will be published subsequently.

\section{Cathodic current/voltage curves at higher voltages}

A set of cathodic experiments were performed at voltages between 0.8 and $1.5 \mathrm{~V}$, using platinized platinum electrodes at $25^{\circ} \mathrm{C}$. Figure 7 shows typical results. The region of limiting current already analysed is again observed, but after reaching a voltage about $0.8-0.9 \mathrm{~V}$ a well defined Tafel line appears, with a slope close to

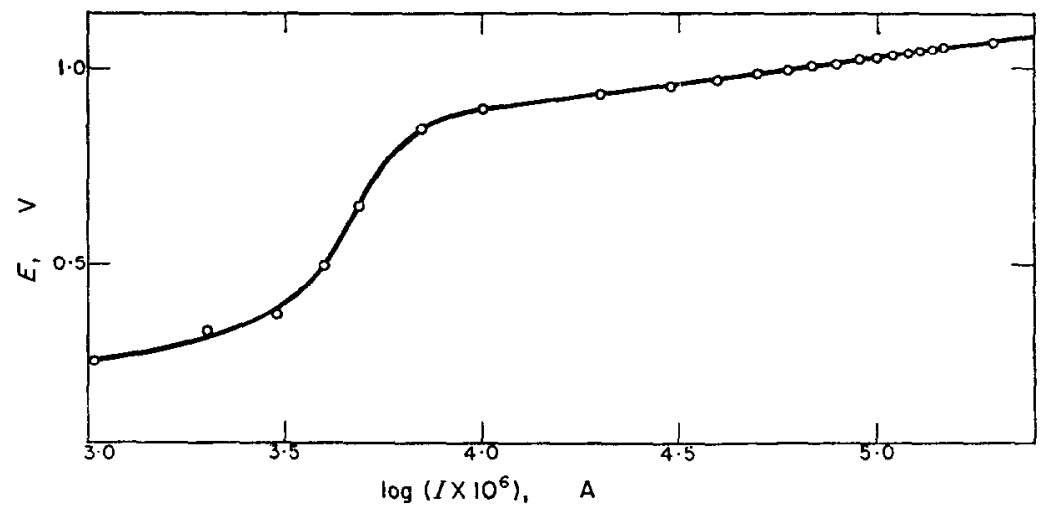

FIG. 7. Cathodic Tafel plot. Region of higher voltages.

Fuming sulphuric acid; $C_{\mathrm{BO}_{\mathrm{a}}}=8.0$ per cent; platinized platinum; $25^{\circ} \mathrm{C}$.

$2 \cdot 3(2 R T / F)$. At that voltage a clear hydrogen evolution begins to take place and simultaneously the oleum acquires a blue tinge. The apparent exchange cd, $\left(i_{0}\right)_{\mathrm{c}, 2}$, extrapolated to $E=0$, was about $10^{-9} \mathrm{~A} / \mathrm{cm}^{2}$. Results are assembled in Table 3 .

The same experiments carried out on bright platinum electrodes yielded no reproducible results, the Tafel line not being well defined at voltages larger than $0.8 \mathrm{~V}$. Macroscopic hydrogen formation and the appearance of the blue colour in the oleum were also found, but the electrode became covered with a yellowish film. The latter was particularly noticeable when the more diluted oleums were employed.

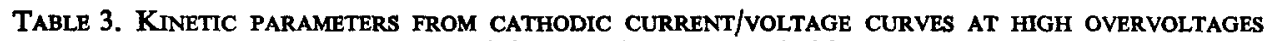
Platinized Pt electrodes; $25 \cdot 0^{\circ} \mathrm{C}$

\begin{tabular}{|c|c|c|c|c|c|}
\hline Run & $\begin{array}{c}C_{\mathrm{SO}_{3}} \\
\% \text { free } \mathrm{SO}_{3} \text { ) }\end{array}$ & $\underset{\mathbf{N}}{\mathrm{C}_{\mathrm{SO}_{2}}}$ & $\underset{\mathrm{V}}{\left(b_{\mathbf{T}}\right)_{\mathbf{c}, \mathbf{2}}}$ & $\begin{array}{c}-\log \left(i_{0}\right)_{\mathrm{c}, \boldsymbol{2}, \boldsymbol{z}=0} \\
\left(i_{0} \text { in } \mathrm{A} / \mathrm{cm}^{2}\right)\end{array}$ & $\begin{array}{c}-\log \left(i_{\mathrm{L}}\right) \\
\left(i_{\mathrm{L}} \text { in } \mathrm{A} / \mathrm{cm}^{2}\right)\end{array}$ \\
\hline $\begin{array}{l}90 \\
91 \\
92\end{array}$ & $\begin{array}{r}7 \cdot 7 \\
7 \cdot 7 \\
15 \cdot 0\end{array}$ & $\begin{array}{l}0.011 \\
0.011 \\
0.033\end{array}$ & $\begin{array}{l}0 \cdot 130 \pm 0.005 \\
0 \cdot 127 \\
0 \cdot 120\end{array}$ & $\begin{array}{l}8 \cdot 9 \pm 0.4 \\
9 \cdot 4 \\
8 \cdot 6\end{array}$ & $\begin{array}{l}2 \cdot 5 \pm 0 \cdot 1 \\
2 \cdot 4 \\
1 \cdot 8\end{array}$ \\
\hline
\end{tabular}

\section{CONCLUSIONS}

From the present study it is concluded that the anodic process comprises the formation of oxygen and persulphuric acids, preferentially permonosulphuric acid. Such products occur simultaneously in the region of the Tafel line with a slope of $2 \cdot 3(2 R T / F)$ and yields are appreciably dependent on temperature. At low voltages, when no 
oxygen is formed, a process occurs, which may probably be due to oxidation of sulphur dioxide although this can not definitely be concluded in the present circumstances. The electrode reaction occurring at the anode is very likely an activated electrochemical process.

The cathodic reaction involves at low voltage the reduction of free sulphur trioxide to sulphur dioxide. As voltage is increased this process becomes mainly a convectivediffusion-controlled process and a definite limiting cd related to free sulphur trioxide concentrations has been assigned.

Beyond the limiting current region a net hydrogen formation and the appearance of disulphur trioxide in the oleums take place. The former is related to a Tafel slope, which is again explained in terms of an electrochemical reaction under activated control. The formation of disulphur trioxide is definitely related to the reduction of sulphur-containing species present in the oleums by hydrogen atoms to sulphur and subsequent dissolution of the latter in the system with the characteristic blue colouring of the electrolyte. However, to evaluate the diffusional contribution in the cathodic reaction, a further study will be attempted before discussing the probable reaction paths of the different electrode processes.

Acknowledgement-This work was done in part with financial support of the Consejo Nacional de Investigaciones Cientificas y Ténicas of Argentina. H. A. G. thanks the Facultad de Ciencias of the Universidad de Cuyo for a leave of absence.

\section{REFERENCES}

1. J. H. Gladstone and A. Tribe, Ber. Deutch. Chem. Ges. 12, 389 (1879).

2. H. HoffMAN, $Z$. Elektrochem. 27, 442 (1921).

3. A. M. Susho, Tr. Dal'nevost Tekh. Inst. Ryb. Prom. Khoz. 3, 121 (1963); Chem. Abstr. 66, 81857 (1967).

4. A. J. Arvía and J. S. W. Carrozza, Electrochim. Acta 11, 1641 (1966).

5. X. DE HeMPTINNE and J. C. JUngers, $Z$. phys. Chem. 15, 137 (1958).

6. K. J. VETTER and D. OTTO, Z. Elektrochem. 60, 1072 (1956).

7. H. A. Videla and A. J. ARví, Electrochim. Acta 10, 21 (1965).

8. A. J. Arvía, A. J. CALANDra and H. A. Videla, Electrochim. Acta 10, 33 (1966).

9. A. J. Arvía, A. J. Calandra and H. A. Videla, Anal. Asoc. Quím. Arg. 54, 143 (1966).

10. A. J. Arvía, F. De Vega and H. A. Videla, Electrochim. Acta, in press.

11. A. J. Arvía, A. J. Calandra and H. A. Videla, Electrochim. Acta, in press.

12. E. C. POTTER, Electrochemistry, p. 102. Cleaver-Hume, London (1956).

13. O. SupINo, Acido Solforico e Superfosfati, p. 304. Hoepli, Milano (1950).

14. F. D. MiLes, Manufacture of Sulphuric Acid, Vol. IV, p. 47. Gurney and Jackson, London (1925).

15. A. I. VoGeL, Quantitative Analytical Chemistry, Vol. 1, pp. 241, 354. Longmans-Green, London (1951).

16. P. PasCal, Nouveau Traité de Chimie Minérale, p. 1495, Vol. XIII. Masson, Paris (1961).

17. V. L. CheIfrTz and I. YA. Rrwlin, J. Angew. Chem. URSS 28, 1291 (1955); Chem. Abstr. 50, $7625 d(1956)$.

18. R. I. Kaganovich, M. Gerowitsch and E. H. EntKejew, Dokl. Akad. Nauk. SSSR 108, 107 (1956); Chem. Abstr. 51, 892e (1957).

19. K. J. Vetrer, Angew. Chem. 73, 279 (1961). 